\title{
MONITORING AND FACTORS AFFECTING LEVELS OF AIRBORNE AND WATER BROMOFORM IN CHLORINATED SEAWATER SWIMMING POOLS
}

\author{
Jean-Luc Boudenne ${ }^{\mathrm{a},{ }^{*},}$, Julien Parinet ${ }^{\mathrm{b}}$, Carine Demelas $^{\mathrm{a}}$, Tarek Manasfi $^{\mathrm{a}}$, Bruno Coulomb $^{\mathrm{a}}$ \\ ${ }^{a}$ Aix Marseille Univ, CNRS, LCE, 13331 Marseille, France \\ ${ }^{b}$ Anses, 14 rue Pierre et Marie Curie, 94700 Maisons-Alfort \\ (E-mail: tarek.manasfi@univ-amu.fr; bruno.coulomb@univ-amu.fr; jean-luc.boudenne@univ-amu.fr)
}

*Corresponding Author: Jean-Luc Boudenne; 3 Place Victor Hugo-Case 29, 13331 Marseille, France; Phone:

+33413551031; Email: jean-luc.boudenne@univ-amu.fr

\section{Abbreviations:}

Br-DPBs (brominated disinfection by-products); $\mathrm{CHBr}_{3}$ (bromoform); $\mathrm{CHCl}_{3}$ (chloroform), $\mathrm{CHCl}_{2} \mathrm{Br}$ (dichlorobromomethane), $\mathrm{CHClBr}_{2}$ (dibromochloromethane); $\mathrm{Clf}$ (free residual chlorine); NPOC (Non Purgeable Organic Carbon); PCA (Principal Component Analysis); $\mathrm{T}_{\text {water }}$ (temperature of water); $\mathrm{T}_{\text {air }}$ (temperature of air); TTHMs (total trihalomethanes = sum of THM-4);

\begin{abstract}
Water and air quality of eight seawater swimming pools using chlorine disinfection was measured during four sampling campaigns, spread on one full-year, and in four thalassotherapy centres located in Southeast of France. Concentrations of trihalomethanes (THMs) in air and in water as well as concentrations of parameters, including non purgeable organic carbon (NPOC), free residual chlorine $\left(\mathrm{Cl}_{\mathrm{f}}\right), \mathrm{pH}$, Kjeldhal Nitrogen $(\mathrm{KN})$, salinity, conductivity, bromide ions and, water and air temperature, were measured. Water and air samples were collected in triplicates morning -at the opening of the pools-, noon and night -at the closing of the pools-, in summer and winter. Data analysis was performed by Principal Component Analysis (PCA) and rotated component matrix, from both data quality and other parameters such as TOC, aromaticity $\left(\mathrm{UV}_{254}\right), \mathrm{pH}$, hygrometry, and free residual chlorine $\left(\mathrm{Cl}_{\mathrm{f}}\right)$. This statistical analysis demonstrates a high correlation between $\mathrm{TOC}, \mathrm{Cl}_{\mathrm{f}}$ and $\mathrm{UV}_{254}$ and THM levels found in air and water, particularly for the major ones $\left(\mathrm{CHBr}_{3}\right.$ in water: 300.0 $\mu \mathrm{g} . \mathrm{L}^{-1}$ mean, $1029.0 \mu \mathrm{g} . \mathrm{L}^{-1}$ maximum; $\mathrm{CHBr}_{3}$ in air : $266.1 \mu \mathrm{g} . \mathrm{m}^{-3}$ mean, $1600.0 \mu \mathrm{g} . \mathrm{m}^{-3}$ maximum, and $\mathrm{CHClBr}_{2}$ in water: $18.9 \mu \mathrm{g} . \mathrm{L}^{-1}$ mean, $81.0 \mu \mathrm{g} . \mathrm{L}^{-1}$ maximum; $\mathrm{CHClBr}_{2}$ in air : 13.6 $\mu \mathrm{g} . \mathrm{m}^{-3}$ mean, $150.0 \mu \mathrm{g} . \mathrm{m}^{-3}$ maximum). These high levels of bromoform $\left(\mathrm{CHBr}_{3}\right)$ are particularly worrisome in such health institutions, even these levels do not exceed the Permissible Exposure Limit (PEL) of $5 \mathrm{mg} \cdot \mathrm{m}^{-3}$ as an 8 hour time-weighted average currently
\end{abstract}


fixed by various administrations, such as Occupational Safety and Health Administration (OSHA).

Keywords : Trihalomethanes, bromoform, air, seawater, swimming pool, brominated compounds.

\section{Introduction}

Thalassotherapy (term coined by the French doctor de la Bonnardière in 1869) has begun establishing health therapy centers for early 1920's, at first in France and then in Great Britain and Germany (Schwartz, 2005). This practice has been defined by the French Medical Academy in 1960 as being the use of seawater, seaweed, sea mud or other sea resources and/or the marine climate for the purpose of medical treatment with a medicinal effect (Crecente et al., 2012). Till 1998, thalassotherapy was covered by French medical insurance as a standard treatment for sore throats, digestive problems, rheumatic arthritis, musculoskeletal injury, development disorders in children, respiratory problems (asthma and bronchitis), endocrine imbalances and skin diseases (e.g. psoriasis) (Roullier, 1991; Shani et al., 1995; Charlier and Chaineux, 2009). The decision to stop reimbursing these cures was not linked to the questioning of the healing properties of this practice, but rather because it has turned into tourism and leisure activities at the end of 1990's. Thalassotherapy is indeed now included in health or spa tourism, which already represents a $\$ 156$ billion global industry but is still an emerging and rapidly growing sector (Johnston et al., 2011; Cockerell, 1996). Furthermore, health or spa tourism is currently one of the tourism products with the highest rates of growth (Farnos, 2003).

Whereas some researchers question the healing properties of seawater cures (Robiner, 1990; Lotti et Ghersetich, 1996; Tsuchiya et al., 2003a; Tsuchiya et al., 2003b; Boulet, 2006), another area of concern is about the impact of chemical treatment on the physical-chemical content of seawater. Indeed, supposed healthy benefits of seawater are partially connected to their mineral salt contents that are believed to be absorbed through the skin during immersion of users (Kazandjieva et al., 2008; Moss, 2010). However, as there is no specific legislation concerning pools and other medical therapy equipments relating to hygiene and security rules, in France and in most of European countries, the thalassotherapy pools use the public swimming pool legislation (Chapuis et al., 2004; ANSES, 2013). This lack of specific legislation on seawater swimming pools implies thus the use of chlorine-based compounds (in 
France, only these compounds are authorized as chemical disinfectants since November 2011) to prevent outbreak diseases caused by feces-associated microbes, such as viruses and bacteria (WHO, 2006; Papadopoulou et al., 2008; Schets et al., 2011). Users represents not only a major source of micro-organisms but also inputs of organic compounds (human body fluids coming from urine, sweat, hair, mucus, skin and/or personal-care products) (SeredyńskaSobecka et al., 2011; Weng and Blatchley III, 2011; Keuten et al., 2012; Duirk et al., 2013; Santos et al., 2012). The combination of a residual disinfectant need (residual of free chlorine higher or equal to $2 \mathrm{mg} / \mathrm{L} \mathrm{Cl}_{2}$ in France) with continuous inputs of organic compounds from users leads to the formation of disinfection by-products (Judd and Bullock, 2003; Weaver et al., 2009; Kanan and Karanfil, 2011; Manasfi et al., 2017a).

Adding of chlorine in rich-bromide waters leads to the rapid oxidation of bromide ions $\left(\mathrm{Br}^{-}\right)$ into hypobromous acid $(\mathrm{HOBr})$, that is readily more reactive with organic matter than hypochlorous acid (HClO) (Kampioti and Stephanou, 2002; Fabbricino and Korshin, 2009; Tian et al., 2013). The occurrence of brominated compounds in seawater swimming pools is poorly documented whereas the toxicity of brominated compounds is known to be greater than their chlorinated analogs (Erdinger et al., 2004; Richardson et al., 2007; Kogevinas et al., 2010; Plewa et al., 2010). In a previous paper (Parinet et al., 2012), occurrence of brominated compounds were investigated in water of seawater swimming pools : bromoform $\left(\mathrm{CHBr}_{3}\right)$ was the most abundant trihalomethane (THM) compound found with levels ranging from 28.7 $\mathrm{mg} / \mathrm{L}$ to $930.7 \mathrm{mg} / \mathrm{L}\left(272.1 \mathrm{mg} / \mathrm{L}\right.$ median) followed by dibromochloromethane $\left(\mathrm{CHCl}_{2} \mathrm{Br}\right)$ with a median level of $14.85 \mathrm{mg} / \mathrm{L}(63.58 \mathrm{mg} / \mathrm{L}$ maximum). Bromoform has been classified as a group B2 (probable human carcinogen) by US.EPA (ATSDR, 1990). Because bromoform can be absorbed into the body through the skin but also by inhalation (Beech et al., 1980; $\mathrm{Xu}$ et al., 2002), it seems thus important to determine the exposure levels of seawater pools' users to bromoform (and to the other THM) not only in water but also in air. This study has thus been carried out to determine the THM-4 (Total THM, TTHM) levels of exposure in air and water of four thalassotherapy centres located in Southeast of France during four sampling campaigns, spread on two days in summer and two days in winter.

\section{Materials and methods}

\subsection{Thalassotherapy centres.}


Four seawater establishments (called after E1, E2, E3 and E4) from Southeast of France, using chlorination agents (bleach or dichloroisocynauric acid) for water disinfection were selected for this study. E1 and E2 possess 2 pools (E1.A, E1.B and E2.A and E2.B); E3 possesses only one pool (E3.A) and E4 possesses 3 pools (E3.A, E3.B and E3.C). Pools E1.A, E2A, E4.A and E4.B are used only for relaxing or swimming activities (notice that E4.A is not connected to other basins -E4.B and E4.C- in this establishment and is not heated), whereas E1.B, E2.B and E4.C are used only for sport activities. E3.A is used equally for relaxing or sport activities. Globally, water temperature of pools devoted to swimming or relaxing are lower $\left(29-32{ }^{\circ} \mathrm{C}\right)$ than those used for sport activities $\left(33-34{ }^{\circ} \mathrm{C}\right)$. These temperature are preset and kept constant, whatever the season, in the range measured. All the swimming pools are disinfected continuously by bleach except E4.A and E4.C, which are disinfected once a week by dichloroisocyanuric acid. The hydraulic characteristics and mean daily frequentation of the whole pools are presented in Table S1.

Table S1: Functional parameters of the basins studied

\begin{tabular}{|c|c|c|c|c|c|c|c|c|c|}
\hline $\begin{array}{l}\text { Establishment } \\
\text { code }\end{array}$ & $\begin{array}{l}\text { Number } \\
\text { of basins }\end{array}$ & Code basin & $\begin{array}{c}\text { Temperature } \\
\text { of water }\end{array}$ & $\begin{array}{c}\text { Surface } \\
\left(\mathrm{m}^{2}\right)\end{array}$ & $\begin{array}{c}\text { Volume } \\
\left(\mathrm{m}^{3}\right)\end{array}$ & $\begin{array}{l}\text { Depth } \\
\text { Max-min } \\
\text { (m) }\end{array}$ & $\begin{array}{l}\text { Type of } \\
\text { filtration }\end{array}$ & $\begin{array}{l}\text { Mean daily } \\
\text { frequentation }\end{array}$ & $\begin{array}{c}\text { Daily } \\
\text { renewal of } \\
\text { water }(\%)\end{array}$ \\
\hline \multirow{2}{*}{ E1 } & \multirow{2}{*}{2} & E1.A & $29.6^{\circ} \mathrm{C}$ & 91 & 160 & $2.2-0.8$ & sand & 65 & $15 \%$ \\
\hline & & E1.B & $32.3^{\circ} \mathrm{C}$ & 24 & 32 & $1.3-1.3$ & $25 \mu \mathrm{m}$ filter & 48 & $5-10 \%$ \\
\hline \multirow{2}{*}{ E2 } & \multirow{2}{*}{2} & E2.A & $29.4^{\circ} \mathrm{C}$ & 143 & 193 & $1.3-1.5$ & sand & 48 & $20 \%$ \\
\hline & & E2.B & $32^{\circ} \mathrm{C}$ & 19 & 24 & $1-1.3$ & sand & 16 & $20 \%$ \\
\hline E3 & 1 & E3.A & $31.5^{\circ} \mathrm{C}$ & 110 & 130 & $1.2-1.2$ & sand & 31 & $5 \%$ \\
\hline \multirow{3}{*}{ E4 } & \multirow{3}{*}{3} & E4.A & $20.1^{\circ} \mathrm{C}$ & 5 & 5 & $1-1$ & sand & 1 & $\mathrm{Uk}^{*}$ \\
\hline & & E4.B & $29.7^{\circ} \mathrm{C}$ & 150 & 200 & $1.3-2.5$ & sand & 30 & $\mathrm{Uk}^{*}$ \\
\hline & & E4.C & $33.2^{\circ} \mathrm{C}$ & 17 & 25 & $1.3-1.3$ & sand & 40 & $\mathrm{Uk} \mathrm{k}^{*}$ \\
\hline
\end{tabular}

* Uk: Unknown

These indoor-swimming pools received seawater from the Mediterranean Sea. Physicalchemical and chemical quality of raw seawaters feeding these pools are reported in Table S2. Physico-chemical parameters (conductivity, $\mathrm{pH}$, turbidity, water and air temperature, hygrometry, total residual chlorine) were recorded on-site at the time of sampling. Total residual chlorine was measured (Urbansky et al., 2000) and the other physico-chemical parameters were determined with specific electrodes. Free and combined bromine were determined by the $N$ - $N$-diethyl-p-phenylenediamine (DPD) colorimetric method (Lourencetti 
et al., 2012). Bromide and chloride were measured with an ICS-3000 Dionex ion chromatography system using a $30 \mathrm{mM} \mathrm{NaOH}$ eluent at $1.5 \mathrm{ml} \cdot \mathrm{min}^{-1}$ and $30^{\circ} \mathrm{C}$.

\begin{tabular}{|c|c|c|c|c|c|c|c|c|}
\hline \multirow{2}{*}{$\begin{array}{c}\text { Establishment code } \\
\text { Parameters }\end{array}$} & \multicolumn{2}{|c|}{ E1 } & \multicolumn{2}{|c|}{$\overline{E 2}$} & \multicolumn{2}{|c|}{ E3 } & \multicolumn{2}{|c|}{$\overline{E 4}$} \\
\hline & $\begin{array}{l}\text { Mean } \\
\text { value }\end{array}$ & SD & $\begin{array}{l}\text { Mean } \\
\text { value }\end{array}$ & $\mathrm{SD}$ & $\begin{array}{l}\text { Mean } \\
\text { value }\end{array}$ & SD & $\begin{array}{l}\text { Mean } \\
\text { value }\end{array}$ & $\mathrm{SD}$ \\
\hline $\mathrm{pH}$ & 8.12 & 0.05 & 7.47 & 1.44 & 7.92 & 0.13 & 8.08 & 0.08 \\
\hline $\mathrm{TOC}(\mathrm{mg} / \mathrm{L} \mathrm{C})$ & 3.1 & 2.1 & 2.0 & 1.5 & 3.6 & 0.0 & 2.7 & 2.1 \\
\hline $\mathrm{TN}(\mathrm{mg} / \mathrm{L})$ & 0.2 & 0.2 & 0.9 & 0.3 & 1.7 & 0.4 & 2.1 & 1.4 \\
\hline $\mathrm{UV}_{254}\left(\mathrm{~cm}^{-1}\right)$ & 0.03 & 0.02 & 0.02 & 0.00 & 0.03 & 0.02 & 0.02 & 0.01 \\
\hline SUVA (L/m*mg C) & 0.75 & 0.46 & 1.3 & 1.2 & 1.5 & 1.3 & 1.0 & 0.5 \\
\hline $\mathrm{Br}(\mathrm{mg} / \mathrm{L})$ & 86.2 & 10.2 & 80.7 & 17.2 & 70.0 & 21.3 & 90.7 & 3.8 \\
\hline $\mathrm{Cl}^{-}(\mathrm{g} / \mathrm{L})$ & 20.0 & 1.2 & 20.0 & 2.5 & 17.3 & 1.5 & 21.6 & 7.6 \\
\hline Conductivity $(\mathrm{mS} / \mathrm{cm})$ & 54.7 & 0.9 & 55.2 & 1 & 51.2 & 4.5 & 48.9 & 2.1 \\
\hline Salinity $(g / L)$ & 35.7 & 0.3 & 36.0 & 0.4 & 34.0 & 1.4 & 33.8 & 1.4 \\
\hline
\end{tabular}

$\mathrm{TOC}=$ Total organic carbon, expressed in $\mathrm{mgC} / \mathrm{L} ; \mathrm{TN}=$ Total nitrogen, expressed in $\mathrm{mg} \mathrm{N} / \mathrm{L} ; \mathrm{UV}_{254}=\mathrm{Absorbance}$ of sample at $254 \mathrm{~nm} ; \mathrm{SUVA}$ $=$ Specific absorbance at $254 \mathrm{~nm}$ expressed following: $\mathrm{SUVA}=\mathrm{UV}_{254} /(\mathrm{TOC} \times 100)$.

Water and air were sampled in triplicate at the opening and, at the closing of the basins, during two consecutive days in winter (February 2016) and two consecutive days in summer (August 2016), to study the potential influences of basin frequentation (higher frequentation leading to higher organic load in the pools), and of potential supplementary organic inputs from bathers in summer (e.g., sweat, sunscreens). Indeed, as observed during previous campaigns, thalassotherapy user behaviour pattern in summer, alternatively consists in selftanning outside the pools and in cooling himself down inside the pools, bringing thus in the pools a cocktail of organic compounds ready to react with $\mathrm{HOBr}$ (Manasfi et al., 2016; Manasfi et al., 2017b). Moreover, people who attend thalassotherapy centres to be older in winter ("curist" period) than in summer ("non-curist" period, including mainly families accompanied with children). Overall, the number of bathers is the same in winter than in summer (Table S1).

\subsection{Sampling and analysis of water and air}

3 air and 3 water samples were collected per day and per pool $(1 \times 2$ in the morning, $1 \times 2$ at noon and $1 \times 2$ at the closing of the pools. The total number of water (or air) samples is thus 6 ( $\times 2$ for duplicates) in winter and $6(\times 2$ for duplicates $)$ in summer.

Samples for TTHM analysis in the air were collected during $30 \mathrm{~min}$ on a $150 \mathrm{mg}$ NIOSH charcoal tube (MSA AUER Gmbh, Berlin, Germany) connected to a pump Escort ELF (MSA AUER Gmbh, Berlin, Germany) at a flow rate of $1 \mathrm{~L} \cdot \mathrm{min}^{-1}$. The air sampling was spiked at 20 $\mathrm{cm}$ above the surface of the swimming pool. The charcoal was then eluted in $5 \mathrm{~mL}$ of toluene (Analytical grade, Sigma-Aldrich) in an ultrasonic bath for 5 min. 
TTHM in air were analyzed by Gas Chromatography coupled to an Electron Capture Detection (GC-ECD). Separation of chloroform $\left(\mathrm{CHCl}_{3}\right)$, dichlorobromomethane $\left(\mathrm{CHCl}_{2} \mathrm{Br}\right)$, dibromochloromethane $\left(\mathrm{CHClBr}_{2}\right)$ and bromoform $\left(\mathrm{CHBr}_{3}\right)$ in air was carried out using a Perkin Elmer (Norwalk, CT, USA) GC Model Clarus 580 equipped with ${ }^{63} \mathrm{Ni}$ ECD system and split-splitless injector was used. Helium 5.0 was used as carrier gas at a programmed flow of $1 \mathrm{~mL} / \mathrm{min}$. For separation, a capillary column DB5-ms $(30 \mathrm{~m} \times 0.25 \mathrm{~mm} \times 1 \mu \mathrm{m})$ Perkin Elmer (Norwalk, CT, USA) was employed. The calibration ranges, the limits of detection and the RSD were evaluated based on the addition of $50 \mu \mathrm{L}$ of a THM's solution at $1 \mathrm{mg} / \mathrm{ml}$ on 7 charcoal tubes and where then extracted by $2 \mathrm{~mL}$ of Toluene. The detection limits were determined for an air sample of $30 \mathrm{~L}$. The extraction efficiency was calculated based on the addition of $0.1 \mathrm{~mL}$ of a THM's solution at $1 \mathrm{mg} \cdot \mathrm{mL}^{-1}$ on 4 charcoal tubes and then eluted by 2 $\mathrm{mL}$ of toluene. All these analytical features are given in Table S3.

Table S3: Analytical conditions and performances for the measurement of THM in air by GC-ECD in seawater swimming pools

\begin{tabular}{|c|c|c|c|c|}
\hline & \multicolumn{4}{|c|}{ Trihalomethanes (THMs) in air } \\
\hline & $\mathrm{CHCl}_{3}$ & $\mathrm{CHCl}_{2} \mathrm{Br}$ & $\mathrm{CHClBr}_{2}$ & $\mathrm{CHBr}_{3}$ \\
\hline Analytical conditions & $\begin{array}{rr}\text { GC } & \text { Perkin } \\
- & \text { Injec } \\
- & \text { Colu } \\
- & \text { Carr } \\
- & \text { Ove } \\
\text { ECD } & \text { (Perkin } \\
- & \text { Tem } \\
- & \text { Offs } \\
- & \text { Carr }\end{array}$ & $\begin{array}{l}\text { arus } 580) \\
\text { erature: } 21 \\
-5 \mathrm{~ms}(30 \mathrm{~m} \\
\text { [e): } 1 \mathrm{~mL} / \mathrm{m} \\
\text { atures: } 100 \\
\text { larus } 580) \\
280^{\circ} \mathrm{C} \\
\text { 2): } 30 \mathrm{~L} / \mathrm{m}\end{array}$ & $\begin{array}{l}\text { plit to } 0.3 \mathrm{n} \\
\mathrm{mm} \times 1 \mu \mathrm{r} \\
\mathrm{min}), 40^{\circ} \mathrm{C}\end{array}$ & : 30$)$ \\
\hline Range $(\mu \mathrm{g} / \mathrm{L})$ & \multicolumn{4}{|c|}{0 to $500 \mu \mathrm{g} / \mathrm{L}$ in Toluene } \\
\hline Extraction efficiency (\%) & 80 & 60 & 76 & 77 \\
\hline Retention time (min) & 3.09 & 3.82 & 5.49 & 8.24 \\
\hline $\mathrm{R}^{2}$ & 0.99 & 0.98 & 0.99 & 0.99 \\
\hline $\begin{array}{l}\text { Limits of detection } \\
\left(\mu \mathrm{g} / \mathrm{m}^{3}\right)\end{array}$ & 2.5 & 1.4 & 1.9 & 2.3 \\
\hline RSD & $5 \%$ & $4 \%$ & $4 \%$ & $4 \%$ \\
\hline
\end{tabular}

Sample for TTHM analysis in water were collected in $60 \mathrm{~mL}$ glass bottles, filled until overflowing with pool water and tightly sealed with a PTFE-lined screw cap. The water sampling was carried out at $20 \mathrm{~cm}$ under the surface of the swimming pool. Prior to sampling, $0.1 \mathrm{~mL}$ of 100 g. $\mathrm{L}^{-1}$ ascorbic acid was added to each $60 \mathrm{~mL}$ bottles to quench any residual chlorine reaction (Lee et al., 2010). Samples were also collected in 1-L glass bottles for analysis of Total Organic Carbon (TOC), Total Nitrogen (TN), UV absorbance at $254 \mathrm{~nm}$ $\left(\mathrm{UV}_{254}\right)$, bromide and chloride. All samples were refrigerated at $4{ }^{\circ} \mathrm{C}$ until analysis.

Analysis of TTHM in seawater swimming pools was carried out by headspace-gas chromatography/mass spectrometry (HS-GC-MS) in Electron Impact (EI) mode. Separation 
of chloroform $\left(\mathrm{CHCl}_{3}\right)$, dichlorobromomethane $\left(\mathrm{CHCl}_{2} \mathrm{Br}\right)$, dibromochloromethane $\left(\mathrm{CHClBr}_{2}\right)$ and bromoform $\left(\mathrm{CHBr}_{3}\right)$ in water was carried out using a Varian Saturn 2000 gas chromatograph (Varian Inc., Walnut Creek, CA, USA) equipped with electronic flow control (EFC) and a 1079 universal capillary injector that allows programmed temperature injection (a PTV injection port). The gas chromatograph was also equipped with an autosampler (CombiPAL autosampler, CTC Analytics) for 32 headspace vials composed of an oven for sample heating/headspace generation and a robotic arm where the headspace syringe was placed. Helium was employed as carrier gas. The operating conditions of the headspace are presented in Table S3. Then $1 \mathrm{~mL}$ of the vial headspace was injected in the GC inlet heated at $140{ }^{\circ} \mathrm{C}$, operated in splitless mode and equipped with a split open deactivated insert liner of 5 $\mathrm{mm}$ OD $\times 54 \mathrm{~mm} \times 3.4 \mathrm{~mm}$ ID (Varian Inc., Walnut Creek, CA, USA). The column temperature was set at $50{ }^{\circ} \mathrm{C}$ and remains constant during $5 \mathrm{~min}$. After this time, the temperature raised up to $220{ }^{\circ} \mathrm{C}$ at $10{ }^{\circ} \mathrm{C} / \mathrm{min}$. A constant column flow of $1.5 \mathrm{~mL} \cdot \mathrm{min}^{-1}$ of helium was used. An Agilent FactorFourVF-624 ms fused silica column of $60 \mathrm{~m} \times 0.32 \mathrm{~mm}$ i.d. and $1.4 \mu \mathrm{m}$ of film size (Agilent, Santa Clara, CA, USA) was used for chromatographic separation. Full scan data were acquired under the following: mass range 45-260 $\mathrm{m} / \mathrm{z}$, scan time $1 \mathrm{~s}$, solvent delay $10 \mathrm{~min}$, manifold temperature $120^{\circ} \mathrm{C}$, and emission current $20 \mu \mathrm{A}$.

The limits of detection and the RSD, presented in Tables S3 and S4, have been evaluated based on 7 samples at $0.1 \mu \mathrm{g} / \mathrm{L}$ of each THM. The recoveries have been evaluated based on 4 seawater samples at 1 and $20 \mu \mathrm{g} / \mathrm{L}$ of each THM.

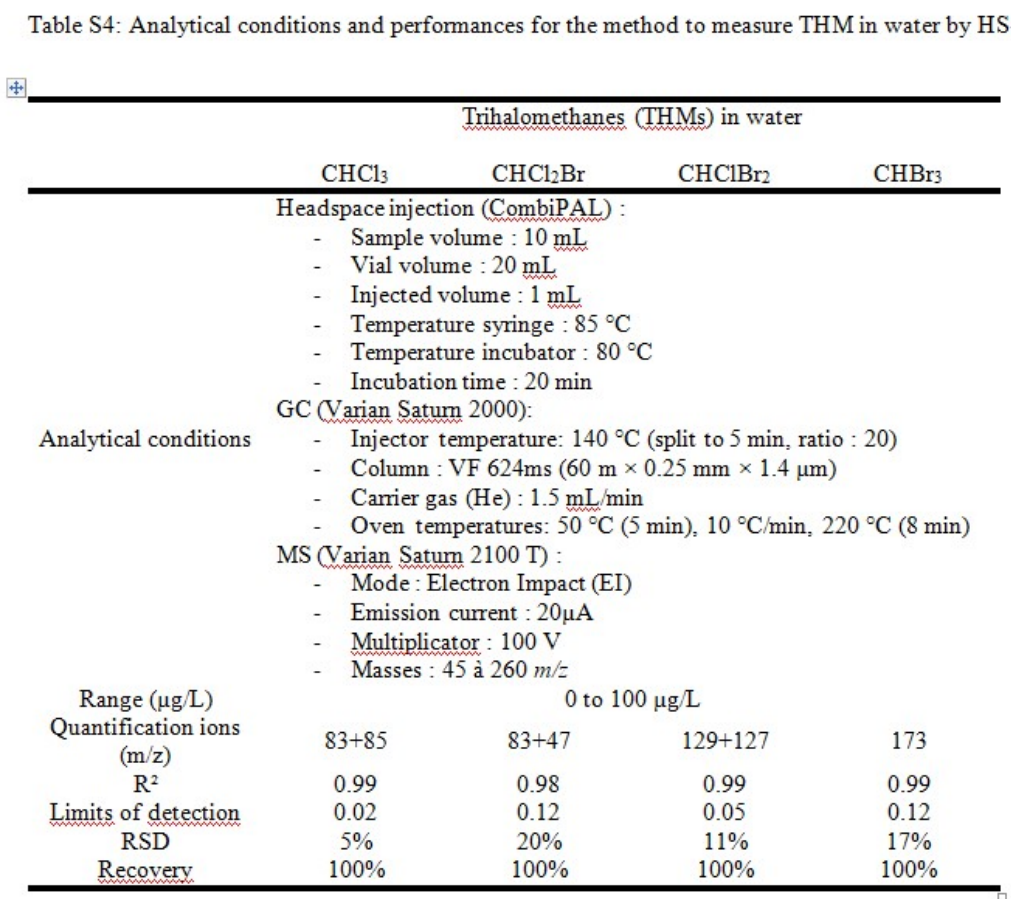


Details about oven program, sources of chromatographic standards, quantifications, recoveries and methods of limits of detection of the analytes are reported in the Supporting Information (Table S4).

\subsection{Statistical Analysis}

Statistical analyses were performed using SPSS statistics 17.0 (49), downloadable software for analyzing data, distributed by Softonic ${ }^{\circledR}$. The taking into account of a large number of variables and the comparative study of different waters from seawater swimming pools has imposed us to use multidimensional statistical data processing. Principal Component Analysis, which is the tool of choice for this type of study, was therefore selected.

The objective of Principal Component Analysis (PCA) was to help differentiate between the different physical-chemical parameters involved in the appearance of disinfection by-products in water and air. Principal Component Analysis aims to turn the original variables (physicalchemical parameters) into new variables, principal components (PC), which are orthogonal and non-inter-correlated. The PCs are ordered in such a way that the first component represents the largest fraction of the total data variance. In order to evaluate the influence of each variable in the PCs, a varimax rotation is generally used to obtain the rotator factor loadings, which represent the contribution of each variable to each of the principal components obtained. The contribution of each variable to the construction of a component can be evaluated through the coefficient of correlation (r) between the variable and component. Together these coefficients make up the matrix of components. This matrix helps us to understand the various processes involved.

All statistical processing of the data collected was carried out using the statistics software v. 17 from SPSS $®$.

\section{Results and discussion}

\subsection{Occurrence of TTHM}

\subsubsection{TTHM in water}

As previously observed in such seawater swimming pools (Parinet et al., 2012), $\mathrm{CHBr}_{3}$ represent the THM with the highest amount found $\left(300.0 \mu \mathrm{g} . \mathrm{L}^{-1}\right.$ mean, $1029.0 \mu \mathrm{g} . \mathrm{L}^{-1}$ maximum), about $95 \%$ of the sum of TTHM, followed by $\mathrm{CHClBr}_{2}, 4$ to $5 \%$ of the sum of 
THM-4 (18.9 $\mu \mathrm{g} . \mathrm{L}^{-1}$ mean, $81.0 \mu \mathrm{g} . \mathrm{L}^{-1}$ maximum), $\mathrm{CHBrCl}_{2}\left(0.3 \mu \mathrm{g} . \mathrm{L}^{-1}\right.$ mean, $2.2 \mu \mathrm{g} . \mathrm{L}^{-1}$ maximum) and $\mathrm{CHCl}_{3}\left(0.1 \mu \mathrm{g} . \mathrm{L}^{-1}\right.$ mean, $0.9 \mu \mathrm{g} . \mathrm{L}^{-1}$ maximum) (Figure 1A). The larger presence of brominated compounds as compared to chlorinated compounds results from the rapid formation of hypobromous acid $(\mathrm{HBrO})$ and hypobromite ions $\left(\mathrm{BrO}^{-}\right)$, when chlorinebased disinfectant are added into bromide-rich waters (Manasfi et al., 2017a). As a halogenating agent, bromine is usually more reactive than chlorine especially with body fluids compounds, brought by swimmers or bathers, leading to the formation of brominated products (Manasfi et al., 2017b).
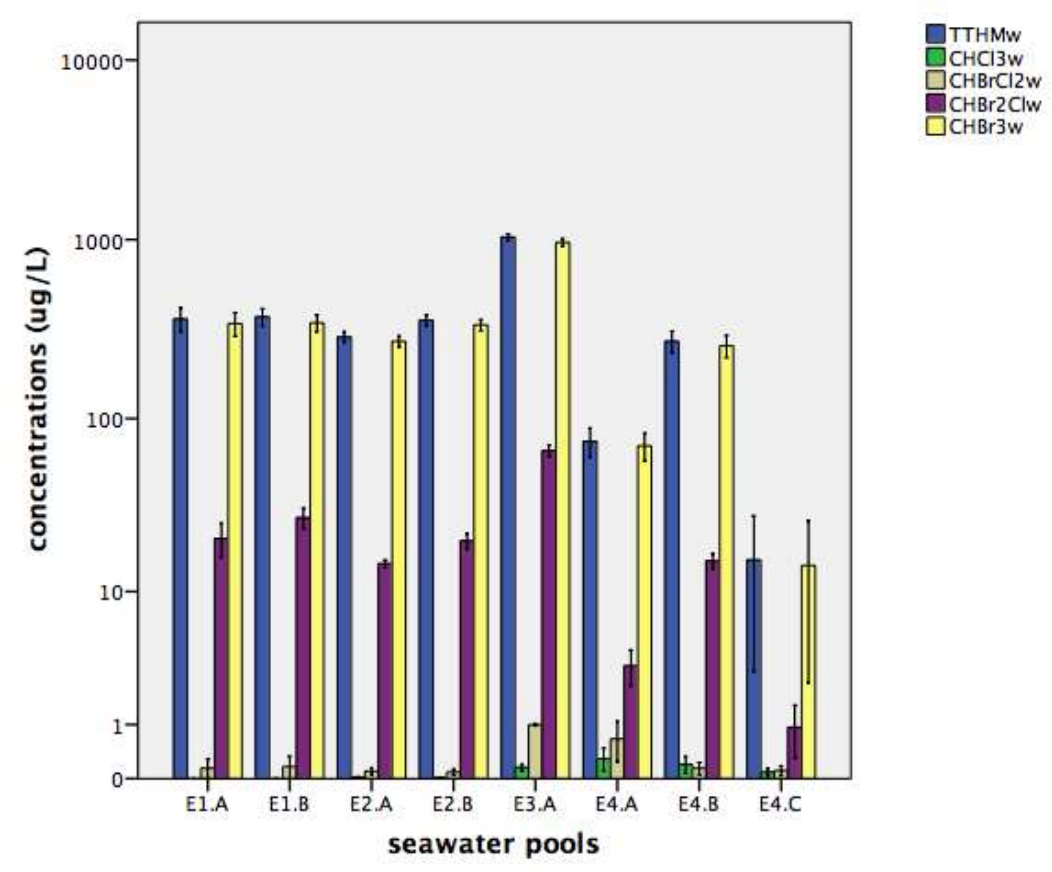

Figure 1A : THMs concentrations (logarithmic scale) in the waters of the different swimming pools studied

Levels were very different between establishments and even within the same establishments and could be explained by temperature of water $\left(20.1\right.$ to $\left.33.2{ }^{\circ} \mathrm{C}\right)$, activities within pools (relaxing or swimming $v s$ aquagym), hydraulic residence times (rate and frequency of water renewal) and mean daily frequentation of pools. Three pools are distinguished from others:

- E3.A with TTHM (1072.1 $\mu$ g.L. $\mathrm{L}^{-1}$ mean, $1092.9 \mu \mathrm{g} . \mathrm{L}^{-1}$ maximum), $\mathrm{CHCl}_{3}$ (0.1 $\mu \mathrm{g} . \mathrm{L}^{-1}$ mean, $0.2 \mu \mathrm{g} . \mathrm{L}^{-1}$ maximum), $\mathrm{CHBrCl}_{2}\left(1.0 \mu \mathrm{g} . \mathrm{L}^{-1}\right.$ mean, $1.1 \mu \mathrm{g} / \mathrm{L}$ maximum $), \mathrm{CHClBr}_{2}$ (66.0 $\mu \mathrm{g} . \mathrm{L}^{-1}$ mean, $81.0 \mu \mathrm{g} . \mathrm{L}^{-1}$ maximum) and $\mathrm{CHBr}_{3}\left(964.7 \mu \mathrm{g} . \mathrm{L}^{-1}\right.$ mean, $1029.0 \mu \mathrm{g} / \mathrm{L}$ maximum). $\mathrm{CHBr}_{3}$ levels is 3 to 10 -fold greater than the others pools. 
E4.A and E4.C with relatively low levels of TTHM, as compared to other pools with respectively: TTHM $\left(81.0 \mu \mathrm{g} . \mathrm{L}^{-1}\right.$ and $3.0 \mu \mathrm{g} . \mathrm{L}^{-1}$ means, $119.6 \mu \mathrm{g} . \mathrm{L}^{-1}$ and $6.7 \mu \mathrm{g} . \mathrm{L}^{-1}$ maximums $), \mathrm{CHCl}_{3}\left(0.3 \mu \mathrm{g} . \mathrm{L}^{-1}\right.$ and $0.1 \mu \mathrm{g} . \mathrm{L}^{-1}$ means, $1 . \mu \mathrm{g} . \mathrm{L}^{-1}$ and $0.2 \mu \mathrm{g} . \mathrm{L}^{-1}$ maximums $)$, $\mathrm{CHBrCl}_{2}\left(0.6 \mu \mathrm{g} . \mathrm{L}^{-1}\right.$ and $0.1 \mu \mathrm{g} . \mathrm{L}^{-1}$ mean, $2.2 \mu \mathrm{g} . \mathrm{L}^{-1}$ and $0.3 \mu \mathrm{g} . \mathrm{L}^{-1}$ maximum $), \mathrm{CHClBr}_{2}$ (3.2 $\mu \mathrm{g} . \mathrm{L}^{-1}$ and $1.0 \mu \mathrm{g} . \mathrm{L}^{-1}$ mean, $6.5 \mu \mathrm{g} . \mathrm{L}^{-1}$ and $4.0 \mu \mathrm{g} / \mathrm{L}$ maximum) and $\mathrm{CHBr}_{3}(70.3$ $\mu \mathrm{g} . \mathrm{L}^{-1}$ and $14.3 \mu \mathrm{g} . \mathrm{L}^{-1}$ mean, $111.1 \mu \mathrm{g} . \mathrm{L}^{-1}$ and $74.0 \mu \mathrm{g} . \mathrm{L}^{-1}$ maximum).

We interpreted the discrepancy between these two establishments by a low level of daily renewal of water, probably accompanied by a higher filtration rate, in Establishment 3, whereas Establishment 4 must dilute their seawater pools with tap water. Indeed, bromide levels measured within their pools are below the mean level of bromide found in corresponding raw seawaters (around $76.7 \mathrm{mg} / \mathrm{L}$ in pools $v s 90 \mathrm{mg} / \mathrm{L}$ in seawater)

\subsubsection{TTHM in air}

For the whole seawater pools under study, THM levels in air are related to their levels in waters, with $\mathrm{CHBr}_{3}$ the THM present at the highest level $\left(266.1 \mu \mathrm{g} \cdot \mathrm{m}^{-3}\right.$ mean, $1600.0 \mu \mathrm{g} . \mathrm{m}^{-3}$ maximum) followed by $\mathrm{CHClBr}_{2}\left(13.6 \mu \mathrm{g} \cdot \mathrm{m}^{-3}\right.$ mean, $150.0 \mu \mathrm{g} \cdot \mathrm{m}^{-3}$ maximum), $\mathrm{CHCl}_{3}$ (3.4 $\mu \mathrm{g} . \mathrm{m}^{-3}$ mean, $29.0 \mu \mathrm{g} \cdot \mathrm{m}^{-3}$ maximum $)$ and $\mathrm{CHBrCl}_{2}\left(2.5 \mu \mathrm{g} \cdot \mathrm{m}^{-3}\right.$ mean, $19.0 \mu \mathrm{g} \cdot \mathrm{m}^{-3}$ maximum $)$ (Figure 1B).
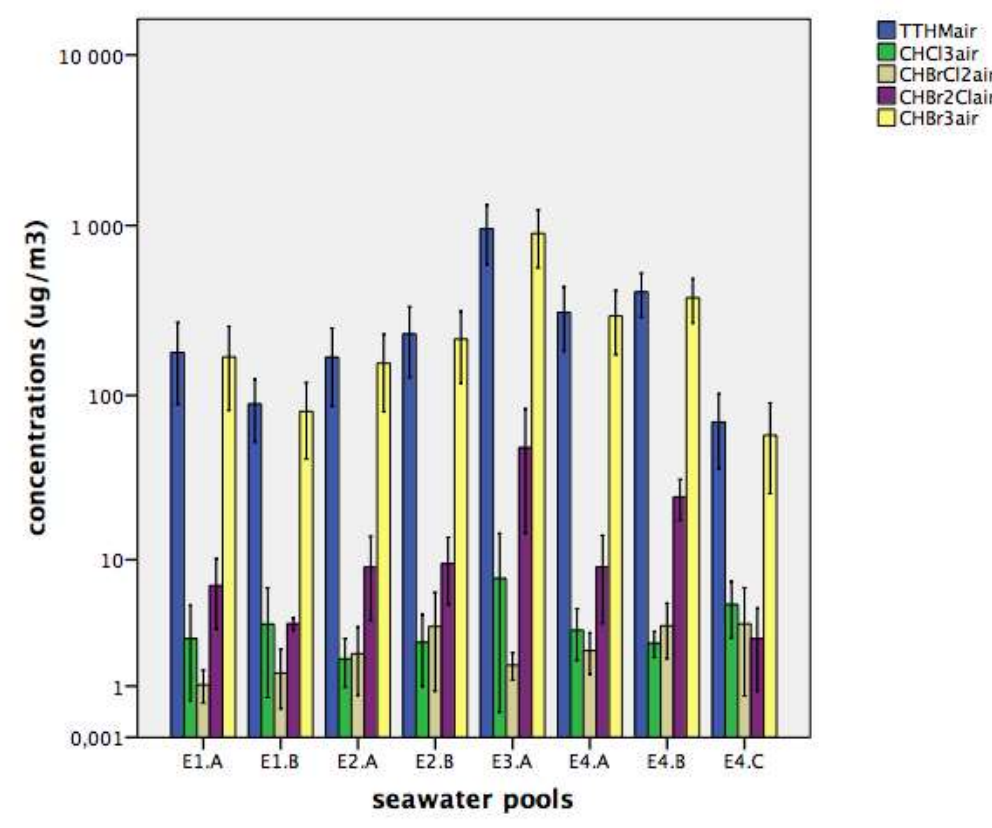

Figure 1B : THMs concentrations (logarithmic scale) in the airs of the different swimming pools studied 
Levels were very different between establishments and even within the same establishments and could be explained by concentrations of the corresponding THM in waters, temperature of water (20.1 to $33.2{ }^{\circ} \mathrm{C}$ ), activities within pools (relaxing or swimming vs aquagym), hydraulic residence times (rate and frequency of water renewal), mean daily frequentation of pools and air residence times (rate and frequency of air renewal). Two pools are distinguished from others:

- E3.A (Figure 1B) with TTHM (955.8 $\mu \mathrm{g} \cdot \mathrm{m}^{-3}$ mean, $1780.0 \mu \mathrm{g} \cdot \mathrm{m}^{-3}$ maximum), $\mathrm{CHCl}_{3}$ (7.5 $\mu \mathrm{g} . \mathrm{m}^{-3}$ mean, $29.0 \mu \mathrm{g} . \mathrm{m}^{-3}$ maximum), $\mathrm{CHBrCl}_{2}\left(1.6 \mu \mathrm{g} . \mathrm{m}^{-3}\right.$ mean, $2.6 \mu \mathrm{g} . \mathrm{m}^{-3}$ maximum), $\mathrm{CHClBr}_{2}\left(48.9 \mu \mathrm{g} \cdot \mathrm{m}^{-3}\right.$ mean, $150.0 \mu \mathrm{g} \cdot \mathrm{m}^{-3}$ maximum) and $\mathrm{CHBr}_{3}(897.7$ $\mu \mathrm{g} . \mathrm{m}^{-3}$ mean, $1600.0 \mu \mathrm{g} \cdot \mathrm{m}^{-3}$ maximum). $\mathrm{CHBr}_{3}$ levels is 3 to 10 -fold greater than the others pools.

- E4.C (Figure 1B) with TTHM (69.5 $\mu \mathrm{g} \cdot \mathrm{m}^{-3}$ mean, $207.0 \mu \mathrm{g} \cdot \mathrm{m}^{-3}$ maximum), $\mathrm{CHCl}_{3}$ (5.0 $\mu \mathrm{g} . \mathrm{m}^{-3}$ mean, $15.0 \mu \mathrm{g} . \mathrm{m}^{-3}$ maximum), $\mathrm{CHBrCl}_{2}\left(3.6 \mu \mathrm{g} \cdot \mathrm{m}^{-3}\right.$ mean, $18 \mu \mathrm{g} . \mathrm{m}^{-3}$ maximum), $\mathrm{CHClBr}_{2}\left(2.8 \mu \mathrm{g} \cdot \mathrm{m}^{-3}\right.$ mean, $12.0 \mu \mathrm{g} \cdot \mathrm{m}^{-3}$ maximum $)$ and $\mathrm{CHBr}_{3}$ (58.0 $\mu \mathrm{g} \cdot \mathrm{m}^{-3}$ mean, $200.0 \mu \mathrm{g} \cdot \mathrm{m}^{-3}$ maximum).

We interpreted the discrepancy of the establishment 3 by a low level of daily renewal of air and the low levels of TTHM in the air of the pool E4.C is due to the chlorination once a week. Whereas in swimming pools supplied with tap water the most commonly detected THM in the air of swimming pools is chloroform -with averaged levels typically ranging from 3.1 to 320 $\mu \mathrm{g} \cdot \mathrm{m}^{-3}$ (Table 1), the predominant molecule found during the present study was bromoform (Figure 1B) with very high levels ranging from $80.0 \mu \mathrm{g} . \mathrm{m}^{-3}$ (pool E2.A) to $1380.0 \mu{\mathrm{g} . \mathrm{m}^{-3}}^{-3}$ (pool E3.A) (964.7 $\mu \mathrm{g} . \mathrm{m}^{-3}$ mean).

Table 1 : Classical THM levels found in indoor air swimming pools

\begin{tabular}{|c|c|c|c|c|c|c|c|}
\hline & & & \multicolumn{4}{|c|}{$\operatorname{Air}\left(\mu \mathrm{g} \cdot \mathrm{m}^{-3}\right)$} & References \\
\hline & & $\mathrm{n}$ & $\mathrm{CHCl}_{3}$ & $\mathrm{CHCl}_{2} \mathrm{Br}$ & $\mathrm{CHClBr}_{2}$ & $\mathrm{CHBr}_{3}$ & \\
\hline \multirow{5}{*}{$\begin{array}{l}\text { Chlorine- } \\
\text { based } \\
\text { disinfectant }\end{array}$} & Italy & 5 & $19-58.6$ & $2.9-13$ & $0.3-6$ & $<$ lod-0.8 & Fantuzzi et al., 2001 \\
\hline & & 1 & $18-61$ & $8.2-23$ & $6.4-22$ & $5.9-22$ & Lourencetti et al., 2012 \\
\hline & & 12 & $11.9-61.6$ & $7.5-23.4$ & $6.1-26.2$ & 4.4-22.6 & Richardson et al., 2010 \\
\hline & Canada & 41 & 20.3-320.4 & $1.3-154.6$ & $<$ lod-204.8 & $<$ lod-102.8 & Tardif et al., 2016 \\
\hline & & 5 & $19-58.6$ & $2.9-14.7$ & $0.3-6$ & $<$ lod-0.8 & Dyck et al., 2011 \\
\hline \multirow{3}{*}{$\begin{array}{l}\text { Bromine- } \\
\text { based } \\
\text { disinfectant or } \\
\text { chlorinated } \\
\text { bromide-rich } \\
\text { waters }\end{array}$} & & 3 & $<$ lod & $<$ lod & 3.6-20.7 & 21.7-240.1 & Manasfi et al., 2017b \\
\hline & Italy & 1 & $1.8-6.9$ & $1.9-4.2$ & $6.4-8.7$ & $55-92$ & Lourencetti et al., 2012 \\
\hline & & 7 & $1.7-4.8$ & $1.7-2.8$ & $6.0-7.7$ & $53-77$ & Marco et al., 2015 \\
\hline & \multicolumn{3}{|c|}{$\mathrm{n}=$ number of pools analyzed } & \multicolumn{3}{|c|}{ - <lod : below the limit of detection } & \\
\hline
\end{tabular}


Bromoform represented between about $95 \%$ of TTHM with a mean of $266.1 \mu \mathrm{g} . \mathrm{m}^{-3}$, followed by dibromochloromethane $\left(\mathrm{CHBr}_{2} \mathrm{Cl}\right)$ representing about $4-5 \%$ of the sum of THM-4. Finally, dichlorobromomethane $\left(\mathrm{CHCl}_{2} \mathrm{Br}\right)$ and chloroform $\left(\mathrm{CHCl}_{3}\right)$ were present at low levels, representing less of $1 \%$ of TTHM. As observed in waters, levels of $\mathrm{CHBr}_{3}$ are higher at the closing of pools, and at higher concentrations in summer than in winter. However, levels of $\mathrm{CHBr}_{3}$ in air are poorly correlated with levels found in water. These trends have also been observed in other studies (Aggazzotti et al., 1995; Bessonneau et al., 2011). Volatilization of THMs could be affected by several factors including water temperature, air temperature, concentration in water, intensity of air circulation (ventilation), and the turbulence in water caused by vigorous activity of pool users (Hsu et al., 2009). In this study, the high THM level in the air in basin E3.A seems related to poor ventilation in this facility (partially defective ventilation system as described by the pool operator).

\subsection{Seasonal variation}

Two temporal variability factors also affect the levels of TTHM found in waters (and air). The levels of $\mathrm{CHBr}_{3}$ found in water (and air) are clearly correlated to time of sampling, with high increase of these levels between opening and closing of the pools (Figure 2), except for pool E4.A, most likely because this basin is not heated and consequently not very frequented.

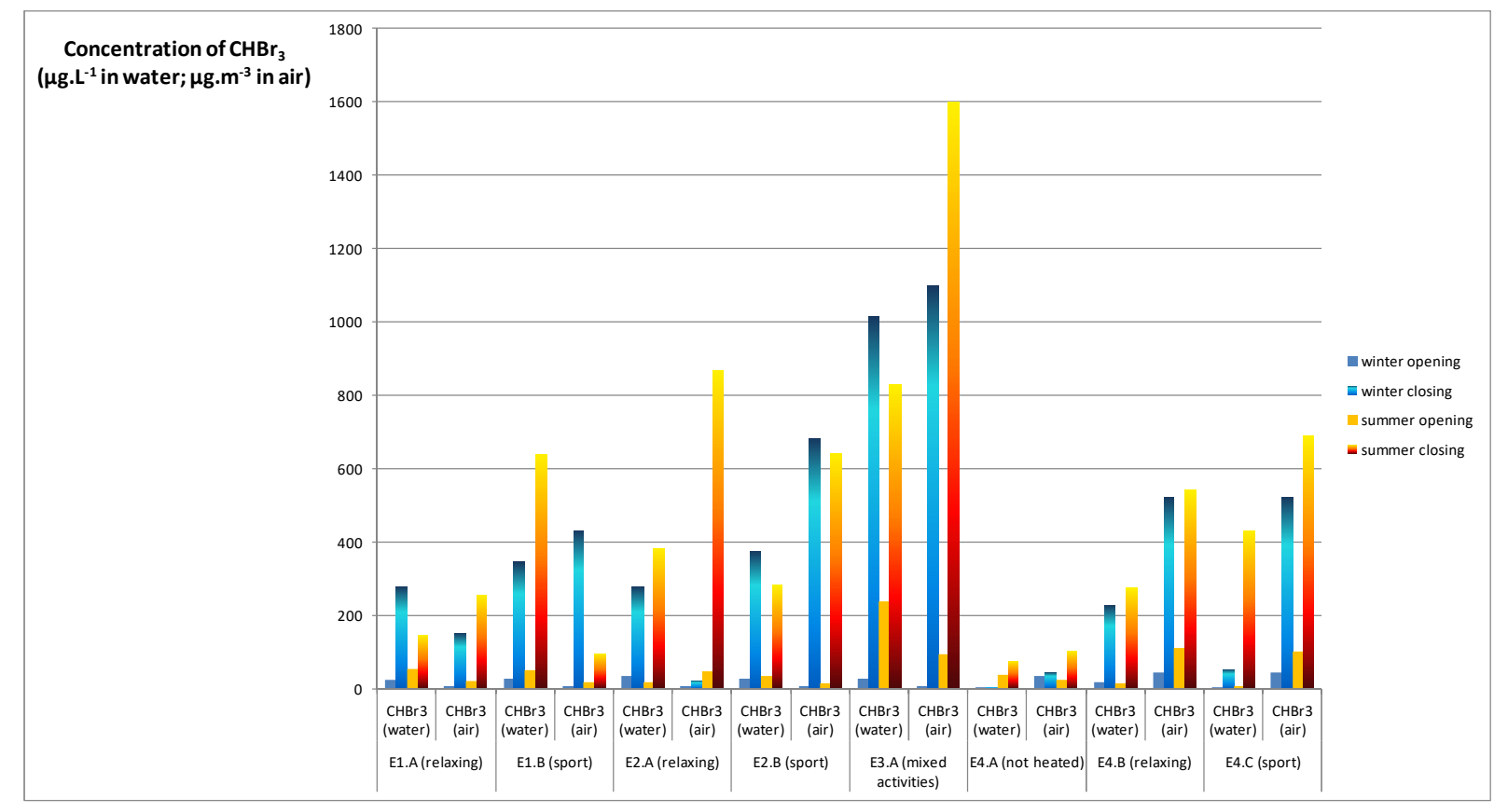

Figure 2 : Temporal variations of $\mathrm{CHBr}_{3}$ in water and air seawater swimming pools under study 
Moreover, levels of $\mathrm{CHBr}_{3}$ are also strongly related to the season, their levels being found to be 1 to 40 -fold higher in summer than in winter. This seasonal influence has already been demonstrated in freshwater chlorinated swimming pools (Bessonneau et al., 2011), where levels of chloroform and chloramines were systematically higher in summer than in winter. This trends is often linked to the highest frequentation of swimming pools in hot season, but this cannot be the only explanation when considering thalassotherapy. Indeed, in such establishments, frequentation is the same in winter than in summer. Input of other compounds than body fluids must thus be raised in summer and, use of sunscreens combined to the absence of pre-swim showering may explained highest levels of DBPs (bromoform) found in water. Indeed, several constituents of sunscreens have been proven to be reactive with chlorine (Duirk et al., 2013; Manasfi et al., 2015).

This relationships is also found when comparing activities carried out in these pools, whatever the season. $\mathrm{CHBr}_{3}$ levels are indeed higher in pools where aquatic activities (aquagym) are offered daily to bathers (E1B vs E1.A; E2B. vs E2.A). Several past studies have already shown that heavy use of pools lead to a highest release of body fluids such as sweat that act as precursors of DBPs (Judd and Bullock, 2003; Keuten et al., 2014; Afifi and Blatchley III, 2015).

However, pools E4.B and E4.C do not show the same pattern of evolution : levels of $\mathrm{CHBr}_{3}$ in the "relaxing" basin are higher than in the "sporting" basin. A possible explanation is the use of botanicals and essential oils when curists (spa patients) are massaged in thalassotherapy centres. The reactivity of these compounds with chlorine has not been yet reported in the literature, but because of their aromatic structure they are supposed to be highly reactive with chlorine (or bromine) and to be very efficient precursors of DBPs.

\subsection{General study on TTHM in air and water using PCA}

The objective of the PCA approach is to identify, in real environments, the water characteristics and the operating conditions that may be involved in the appearance of DBPs and to help better understand the origins of these molecules.

In general, PCAs only produce graphic interpretation resulting from the extraction of the first two components. However, for most aquatic environments, the first four or five components provide other information on the physical-chemical, biological and even climatic processes 
that govern the environment, for which the first two components are not always enough to explain (Legendre and Legendre, 1998; Shirodkar et al., 2009).

In this study, to allow each component to be represented by robust variables, a varimax rotation of different varifactors with factor loading was calculated using eigenvalues greater than 0.3. PCA was applied to normalized data, and so the covariance matrix coincides with the correlation matrix. To examine the suitability of these data for factor analysis, KaiserMeyer-Olkin (KMO) and Bartlett's tests were performed. KMO is a measure of sampling adequacy that indicates the proportion of variance which is common variance, i.e. which might be caused by underlying factors. High KMO values (close to 1) generally indicate that factor analysis may be useful, which is the case in this study: $\mathrm{KMO}=0.567$; if the $\mathrm{KMO}$ test value is less than 0.5 , factor analysis will not be useful. Bartlett's test of sphericity indicates whether the correlation matrix is an identity matrix, which would indicate that variables are unrelated. The significance level is 0 in this study; less than 0.05 indicates that there are significant relationships among variables.

The PCA of the 19 parameters and rotated component matrix obtained for the varimax factor analysis indicate that altogether five components (Kaiser normalization) explain $86 \%$ of the total variance. The Kaiser normalization is a common strategy to select the "right" number of components by selecting components with an eigenvalue $>1$. This value is significant given number of variables taken into account at the outset for the PCA. The interpretation of the processes described for each component can be carried out based on the variables that are used in their construction, we have retained uniquely the parameters in bold in the rotated matrix component (Table 2):

- Component 1, which is built upon the variables: $\mathrm{THM}_{\text {water }}, \mathrm{CHBr}_{3 \text { water }}, \mathrm{CHBr}_{2} \mathrm{Cl}_{\text {wate }}$, NPOC, $\mathrm{Cl}_{\mathrm{f}}$, UV254 (strong positive loadings). This component may explain the presence of the major Br-DBPs in water in relation with precursors like: TOC, UV254 and $\mathrm{Cl}_{\mathrm{f}}$. The presence of $\mathrm{Br}$ DBPs is positively correlated to the aromaticity (UV254), carbonaceous organic matter concentration (NPOC) and chlorine $\left(\mathrm{Cl}_{\mathrm{f}}\right)$. In this study, bromine seems to be not correlated to the component 1 . This is probably explained by the fact that bromine is in large excess (65 mg. $\mathrm{L}^{-1}$ as compared to the $\mu \mathrm{g} . \mathrm{L}^{-1}$ levels of halogenated compounds). - Component 2 is based on the following variables: $\mathrm{CHBrCl}_{2 \text { water }}, \mathrm{CHCl}_{3 \text { water }}$ (strong negative loadings) and conductivity and $\mathrm{Br}^{-}$(strong positive loading). It is a component that may explain the minor chlorinated DBPs concentrations found in the seawater swimming pools are inversely correlated to bromide $\left(\mathrm{Br}^{-}\right)$and consequently to conductivity. 
- Component 3, which is comprised of the variables $\mathrm{THM}_{\mathrm{air}}, \mathrm{CHBr}_{2} \mathrm{Cl}_{\mathrm{ai}} \mathrm{r}, \mathrm{CHBr}_{3}$ air (strong positive loadings). This component may explain the major Br-DBPs concentrations found in the air of seawaters swimming pools.

- Component 4, which is comprised of the variables $\mathrm{CHBrCl}_{2 \text { air }}, \mathrm{CHCl}_{3 \text { air }}$ and hygrometry (strong positive loadings) and $\mathrm{pH}$ (moderate negative loading). This component may explain the minor chlorinated DBPs concentrations found in the air of seawaters swimming pools. These DBPs are correlated to hygrometry and inversely correlated to $\mathrm{pH}$ in water.

- Component 5, where we noted the presence of $\mathrm{T}_{\text {water }}$ and $\mathrm{T}_{\text {air }}$ is the component of temperature. Temperature of the air seems to be independent to DBPs formation, that is not the case for the temperature of the water which is positively correlated to component 1 (loading: 0.425) and component 2 (loading: 0.403).

Table 2: Rotated component matrix

\begin{tabular}{|c|c|c|c|c|c|}
\hline & \multicolumn{5}{|c|}{ Component } \\
\hline & 1 & 2 & 3 & 4 & 5 \\
\hline THHMwater & 0.952 & & & & \\
\hline $\mathrm{CHBr}$ 3water| & 0.952 & & & & \\
\hline $\mathrm{CHBr}_{2} \mathrm{Cl}_{\text {water }}$ & 0.947 & & & & \\
\hline NPOC & 0.789 & -0.408 & & & \\
\hline Clf & 0.732 & & & & -0.302 \\
\hline$U_{254}$ & 0.687 & 0.400 & & & \\
\hline $\mathrm{CHCl}_{3 \text { water }}$ & & -0.901 & & & \\
\hline $\mathrm{CHBrCl}_{2 \text { water }}$ & & -0.891 & & & \\
\hline Conductivity & & 0.852 & & & \\
\hline $\mathrm{Br}$ & & 0.822 & & & \\
\hline THMair & & & 0.913 & & \\
\hline $\mathrm{CHBr}$ 3air & & & 0.910 & & \\
\hline $\mathrm{CHBr}_{2} \mathrm{Cl}_{\text {air }}$ & & & 0.733 & 0.452 & \\
\hline $\mathrm{CHBrCl}_{2 \text { air }}$ & & & & 0.859 & \\
\hline $\mathrm{CHCl} 3 a \mathrm{ir}$ & & & & 0.735 & \\
\hline hygrometry & & & & 0.728 & \\
\hline $\mathrm{pH}$ & -0.405 & & & -0.641 & \\
\hline Tair & & & & & 0.894 \\
\hline Twater. & 0.425 & 0.403 & & & 0.561 \\
\hline
\end{tabular}

Figure 3 represents the score plots of the seawater swimming pools for different campaigns. The component 1 is the component of the major DBPs found in waters and component 3 is the component of the major DBPs found in airs. As we can see on this figure, the swimming 
pools plots of the establishments E1, E2, E3 and E4 are classified on the component 1 as follows:

- E3.A in the positive part of the component 1, which means that the concentrations of DBPs in water are the highest.

- E1.A, E1.B, E2.A and E2.B are in the central part of the component 1, which means that the concentrations of DBPs in water are average and quite similar between the two establishments. We note that these two establishments are in a relatively close geographic area and are very similar in terms of size of the swimming pools and in attendance.

- And finally, E4.A, E4.B and E4.C are in the negative part of the component 1, which means that the concentrations of DBPs in water are the lowest. Nevertheless, we can notice for the E4.B plots, they are relatively close to those of the establishments E1 and E2. This can be explained by the fact that the seawater swimming pools are similar in size and in attendance.

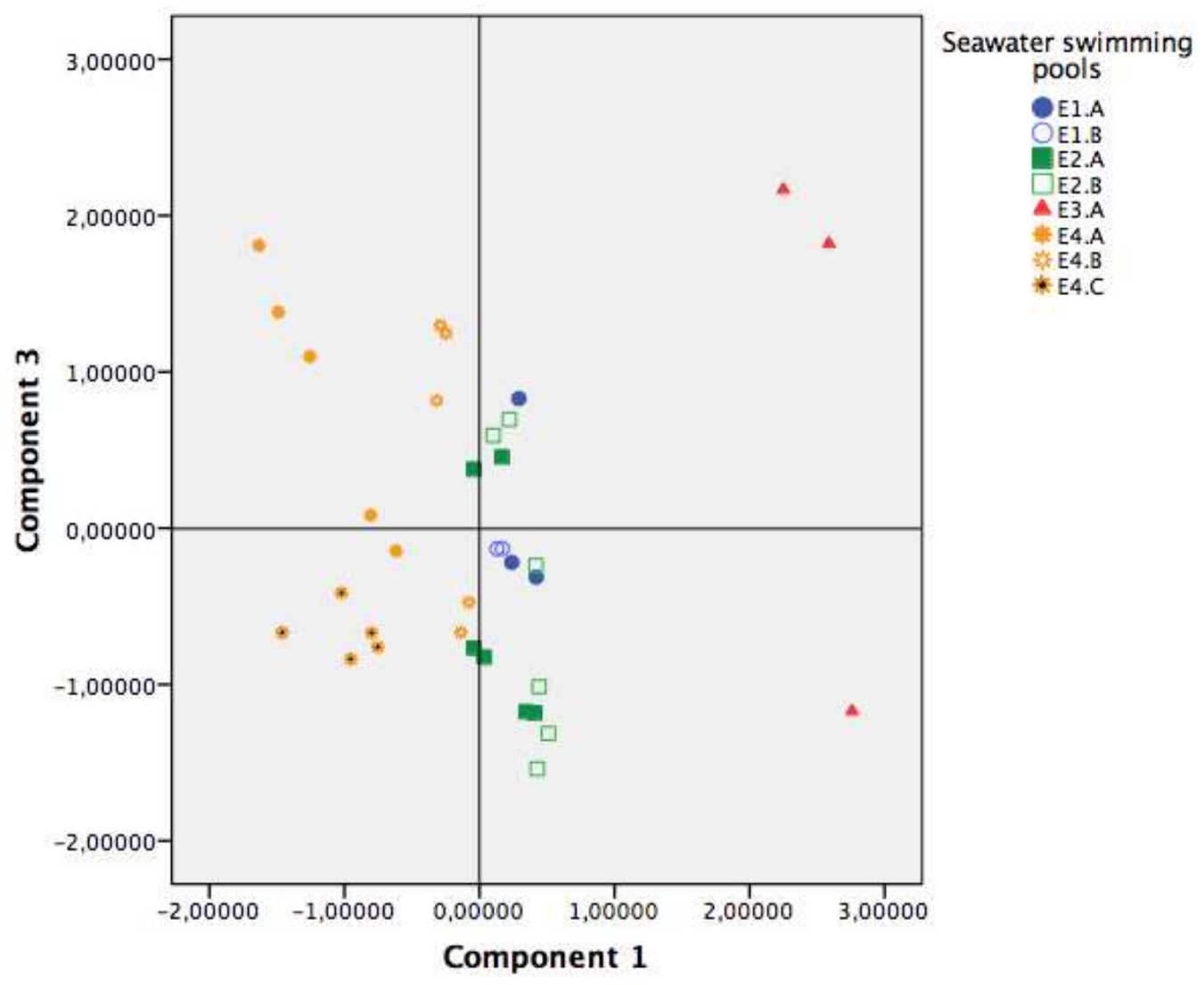

Figure 3: Score plots PC1 vs. PC3 
As we can see on Figure 3, most of the swimming pools plots of the establishments E1, E2, E3 and E4 are scattered along the component 3, which means that the concentrations of DBPs in the air are variables. It is not the case for the swimming pool E4.C, where the plots are not scattered along the component 3 . This can be explained by the fact that there is no ventilation in the halls of this swimming pool and is still closed, all others undergo changes in their concentrations in the air due to ventilation. The seawater swimming pools plots of the establishment E1 are less scattered than seawater swimming pools plots of establishment E2, which indicates a lower variability of DBPs concentrations in seawater swimming pools of the establishment E1, even before we saw that these basins have similar DBPs concentrations in water.

Regarding the establishment E3 and its swimming pool E3.A, we observe that the plots of this swimming pool are scattered along the component 3 , so there is a wide variation in concentrations of DBPs in the air of this swimming pool. The same observations can be made for seawater swimming pools E4.A and E4.B, which are scattered along the component 3 too.

Based on this statistical study, we can conclude that PCA allows to distinguish pools compared to DBPs concentrations found in air and water and help to establish where the pollutions are highest, and how they vary. Moreover, PCA allows to observe the impact of ventilation, and the influence of the raw water quality, size of the swimming pools and attendance.

NPOC, $\mathrm{Cl}_{\mathrm{f}}$ and UV254 are found to be the precursors of THM found in water, particularly to the major ones $\left(\mathrm{CHBr}_{3 \text { water }}\right.$ and $\left.\mathrm{CHBr}_{2} \mathrm{Cl}_{\text {water }}\right)$. It is not the case for the minor ones $\left(\mathrm{CHCl}_{3 \text { water }}\right.$ and $\mathrm{CHBrCl}_{2 \text { water }}$ ), that are only correlated to NPOC.

Bromide concentrations are not linked to the formation of Br-DBPs probably due to their excess in the seawater swimming pools (NPOC -organic loads brought by bathers- act as the limiting reagent).

TTHM concentrations found in the hall air of seawater swimming pools are presumably linked by a non-linear correlation to their concentrations in waters. This conclusion has been done by the fact that they are on four different components (component 1 and 2 for THM in water and component 3 and 4 for THM in air). Perhaps this is due to the operating conditions, particularly the air renewal.

Temperature of water seems to be positively correlated to the formation of Br-DBPs in water (the majors) and negatively to the chlorinated DBPs (the minors). 


\section{Conclusions}

This study shows that in chlorinated seawater pools the speciation of DBPs in the water and air is predominantly brominated. Bromoform is the most abundant species (among THM) found in air and water of seawater swimming pools. These high concentrations related to the suspected carcinogenic effects of THM-Br are high of concern in seawater swimming pools treated with chlorine-based disinfectants. The THM-Br are genotoxic, mutagenic and are activated to mutagens by glutathion-transferase-theta-1 (GSTT1-1) (DeMarini et al., 1997; Kogevinas et al., 2010) and a recent study found higher bladder cancer risks for people expressing GSTT1-1 (Cantor et al., 2010). Bromoform induced sister chromatid exchanges and micronuclei and is considered as a probable human carcinogen by US-EPA (IRIS, 1999; ATDSR, 1990). Dibromochloromethane induced chromosomal aberrations and sister chromatid exchanges (Kogevinas et al., 2010) and is considered to be a probable human carcinogen by US-EPA (ATDSR, 1990).

This study also emphasizes the need to not only improve water treatment systems or to decrease hydraulic retention time of water in pools (rate of renewal of water, rate of filtration rate), but also to improve air treatment systems, as it has already been demonstrated that there is a strong correlation between levels of Br-DBP found in ambient air and in exhaled breath of pool attendants (Fantuzzi et al., 2001). Moreover, the levels of inhaled Br-DBPs are also affected by physical activities of bathers in these pools (Font-Ribera et al., 2016).

Whatever these improvements in air or water treatments, nothing can replace bathers' hygienic behaviour, consisting in a 60 -s pre-swim shower with soapy water, and by wearing clean bathing suits and swimming caps (Keuten et al., 2012).

\section{Acknowledgements}

This research was supported by a grant from the French Agency for Food, Environmental and Occupational Health and Safety (Grant 2009-CRD-21). Tarek Manasfi acknowledges the Doctoral School of "Environmental Sciences" (ED251) at Aix-Marseille University and the French Ministry of Higher Education and Research for the doctoral scholarship.

\section{References}

Afifi, M.Z., Blatchley III, E.R., 2015. Seasonal dynamics of water and air chemistry in an indoor chlorinated swimming pool. Water Res., 68, 771-783.

ANSES (French Agency for Food, Environmental and Occupational Health and Safety), 
2013. Evaluation des risques sanitaires liés aux piscines. Partie II : bains à remous. Ed. ANSES, $202 \mathrm{pp}$ (report in French available at : https://www.anses.fr/fr/system/files/EAUX2007sa0409Ra-2.pdf)

Agency for Toxic Substances and Disease Registry (ATSDR). Toxicological Profile for Bromoform and Chlorodibromomethane. Public Health Service, U.S. Department of Health and Human Services, Atlanta, GA. 1990.

Beech, J.A., Diaz, R., Ordaz, C., Palomeque, B., 1980. Nitrates, chlorates and trihalomethanes in swimming pool water. Am. J. Public Health, 70(1), 79-82.

Bessonneau, V., Derbez, M., Clément, M., Thomas, O., 2011. Determinants of chlorination by-products in indoor swimming pools. Int. J. Hyg. Envir. Heal., 215, 76-85.

Boulet, L.-P., 2006. Algae-induced occupational asthma in a thalassotherapist. Occup. Med. Oxford, 56(4), 282-283.

Cantor, K.P., Villanueva, C.M., Silverman, D.T., Figueroa, J.D., Real, F.X., Garcia-Closas, M., Malats, N., Chanock, S., Yeager, M., Tardon, A., Garcia-Closas, R., Serra, C., Carrato, A., Castaño-Vinyals, G., Samanic, C., Rothman, N., Kogevinas, M., 2010. Polymorphisms in GSTT1, GSTZ1, AND CYP2E1, disinfection by-products, and risk of bladder cancer in Spain. Environ. Health Perspect. 118, 1545-1550. doi:10.1289/ehp.1002206

Chapuis, C., Gardes, S., Tasseau, F., 2004. Management of infectious risk associated with therapeutic pools. Annales de réadaptation et de médecine physique 47, 233-238.

Charlier, R.H., Chaineux, M.C.P., 2009. The healing sea: a sustainable costal ocean resource: thalassotherapy. J. Coastal Res., 25(4), 838-856.

Cockerell, N., 1996. Spas and health resorts in Europe. Travel \& Tourism Analyst, 1, 53-77.

Crecente, J.M., Santé, I., Diaz, C., Crecente R., 2012. A multicriteria approach to support the location of thalassotherapy (seawater therapy) resorts: Application to Galicia region, NW Spain. Landscape Urban Plan., 104, 135-147.

DeMarini, D.M.; Shelton, M.L.; Warren, S.H.; Ross, T.M.; Shim, J.Y.; Richard, A.M.; Pegram, R.A., 1997. Glutathione S-transferase-mediated induction of GC-->AT transitions by halomethanes in Salmonella. Environ. Mol. Mutagen. 30, 440-447.

Duirk, S.E, Bridenstine, D.R., Leslie, D.C., 2013. Reaction of Benzophenone UV Filters in the Presence of Aqueous Chlorine: Kinetics and Chloroform Formation. Water Res., 47(2), $579-587$

Dyck, R., Sadiq, R., Rodriguez, M. J., Simard, S., Tardif, R., 2011. Trihalomethane exposures in indoor swimming pools: A level III fugacity model. Water Res. 45, 5084-5098. 
Erdinger, L., Kühn, K.P., Kirsh, F., Feldhues, R., Fröbel, T., Nohynek, B., Gabrio, T., 2004. Pathways of trihalomethane uptake in swimming pools. Int. J. Hyg. Envir. Heal., 207(6), $571-575$.

Fabbricino, M. Korshin, G.V., 2009. Modelling disinfection by-products formation in bromide-containing waters. J. Hazard. Mater., 168(2-3), 782-786.

Fantuzzi, G., Righi, E., Predieri, G., Ceppelli, G., Gobba, F., Aggazzotti, G., 2001. Occupational exposure to trihalomethanes in indoor swimming pools. Sci. Total Environ., $264,257-265$

Farnos, J., 2003. Condiciones óptimas para un centro de talasoterapia (Optimal conditions for a thalassotherapy resort). Boletín de la Sociedad Española de Hidrología Médica (Bulletin of the Spanish Society of Medical Hydrology), 18(1), 11-15 (in Spanish).

Font-Ribera, L., Kogevinas, M., Schmalz, C., Zwiener, C., Marco, E., Grimalt, J.O., Liu, J.Q., Zhang, X.R., Mitch, W., Critelli, R., Naccarati, A., Heederick, D., Spithoven, J., Arjona, L., de Bont, J., Gracia-Lavedan, E., Villanueva, C.M., 2016 Environmental and personal determinants of the uptake of disinfection by-products during swimming. Environ. Res.149, 206-215. doi: 10.1016/j.envres.2016.05.013

Hsu, H.T., Chen, M.J., Lin, C.H., Chou, W.S., Chen, J.H. Chloroform in indoor swimmingpool air: Monitoring and modeling coupled with the effects of environmental conditions and occupant activities. Water Res., 43, 3693-3704.

Integrated risk information system (IRIS) on bromoform, 1999. U.S. Environmental Protection Agency. National Center for Environmental Assessment, Office of Research and Development, Washington, D.C.

Johnston, K., Puczko, L., Smith, M., Ellis, S., 2011. Global Spa Summit, wellness tourism and medical tourism: Where do spas fit? Global Spa Summit LLC., 123 pp.

http://www.globalspaandwellnesssummit.org/images/stories/pdf/spas_wellness_medical_to urism_report_final.pdf.

Judd, S.J., Bullock, G., 2003. The fate of chlorine and organic materials in swimming pools. Chemosphere, 51(9), 869-879.

Kampioti, A.A., Stephanou, E.G., 2002. The impact of bromide on the formation of neutral and acidic disinfection by-products (DBPs) in Mediterranean chlorinated drinking water. Water Res. 36(10), 2596-2606.

Kanan, A., Karanfil, T., 2011. Formation of disinfection byproducts in indoor swimming pool water: the contribution from filling water natural organic matter and swimmer body fluids. Water Res. 45 (2), 926-932. 
Kazandjieva, J., Grozdev, I., Darlenski, R., Tsankov, N., 2008. Climatotherapy of psoriasis. Clin. Dermatol. 26(5), 477-485.

Keuten, M.G.A., Schets, F.M., Schijven, J.F., Verberk, J.Q.J.C., van Dijk, J.C., 2012. Definition and quantification of initial anthropogenic pollutant release in swimming pools. Water Res. 46(11), 3682-3692.

Keuten, M.G.A., Peters, M.C.F.M., Daanen, H.A.M., de Kreuk, M.K., Rietveld, M.C., van Dijk, J.C., 2014. Quantification of continual anthropogenic pollutants released in swimming pools. Water Res., 53-259-270.

Kogevinas, M., Villanueva, C.M., Font-Ribera, L., Liviac, D., Bustamante, M., Espinoza, F., Nieuwenhuijsen M.J., Espinosa, A., Fernandez, P., DeMarini D.M., Grimalt, J.O., Grummt, Ricard Marcos T., 2010. Genotoxic effects in swimmers exposed to disinfection by-products in indoor swimming pools. Environ. Health Persp. 118(11), 1531-1537.

Lee, J., Jun, M.J., Lee, M.H., Lee, M.H., Eom, S.W., Zoh, K.D., 2010. Production of various disinfection byproducts in indoor swimming pool waters treated with different disinfection methods. Int. J. Hyg. Envir. Heal., 213 (6), 465-474.

Legendre, P. and Legendre, L., 1998. Numerical Ecology. $2^{\text {nd }}$ English edition, Elsevier Sciences, BV, Amsterdam.

Lotti, T.M., Ghersetich, I., 1996. Mineral waters: Instead of soap or better than soap? Clin. Dermatol., 14(1), 101-104.

Lourencetti, C., Grimalt, J.O., Marco, E. Fernandez, P., Font-Ribera, L., Villanueva, C.M., Kogevinas, M., 2012. Trihalomethanes in chlorine and bromine disinfected swimming pools: Air-water distributions and human exposure. Environ. Int., 45, 59-67.

Manasfi, T., Storck, V., Ravier, S., Demelas, C., Coulomb, B., Boudenne, J.-L., 2015. Degradation products of benzophenone-3 in chlorinated seawater swimming pools. Environ. Sci. Technol., 49(15), 9308-9316.

Manasfi, T., De Meo, M., Coulomb, B., Di Giorgio, C., Boudenne, J.-L. Identification of disinfection by-products in Freshwater and Seawater Swimming Pools and Evaluation of Genotoxicity. Environ.Int., 88, 94-102, 2016.

Manasfi, T., Coulomb, B., Boudenne, J.-L. Occurrence, origin and toxicity of disinfection byproducts in chlorinated swimming pools : An overview. Int. J. Hyg. Envir. Heal., corrected proof on-line, 2017a.

http://dx.doi.org/10.1016/j.ijheh.2017.01.005

Manasfi, T., Temime-Roussel, B., Coulomb, B., Vassalo, L., Boudenne, J.-L. Occurrence of brominated disinfection byproducts in the air and water of chlorinated seawater swimming 
pools. Int. J. Hyg. Envir. Heal., 2017b, corrected proof on-line http://dx.doi.org/10.1016/j.ijheh.2017.01.008

Moss, G.A., 2010. Water and health: a forgotten connection? Perspect. Public Heal., 130(5), 227-232.

Papadopoulou, C., Economoua, V., Sakkasa, H., Gousiaa, P., Giannakopoulosc, X., Dontoroua, C., Filioussisa, G., Gessoulid, H., Karanise, P., Leveidiotou, S., 2008. Microbiological quality of indoor and outdoor swimming pools in Greece: Investigation of the antibiotic resistance of the bacterial isolates. Int. J. Hyg. Envir. Heal., 211, 385-397.

Parinet, J., Tabaries, S., Coulomb, B., Vassalo, L., Boudenne, J.-L., 2012. Exposure levels to brominated compounds in seawater swimming pools treated with chlorine. Water Res., $46(3), 828-836$.

Plewa, M.J., Simmons, J.E., Richardson, S.D., Wagner, E.D., 2010. Mammalian cell cytotoxicity and genotoxicity of the haloacetic acids, a major class of drinking water disinfection by-products. Environ. Mol. Mutagen. 51, 871-878.

Richardson, S.D., Plewa, M.J., Wagner, E.D., Schoeny, R., DeMarini, D.M., 2007. Occurrence, genotoxicity and carcinogenicity of regulated and emerging disinfection byproducts in drinking water: a review and roadmap for research. Mut. Res. Gen. Tox. En. $636,178-242$.

Robiner, W.N., 1990. Psychological and Physical Reactions to Whirlpool Baths. J. Behav. Med., 13(2), 157-173.

Roullier B., 1991. Thalassothérapie et crénothérapie pédiatrique. Journal de Pédiatrie et de Puériculture 4(3), 183-187.

Santos A.J.M., Miranda, M.S., Esteves da Silva, J.C.G., 2012. The degradation products of UV filters in aqueous and chlorinated aqueous solutions. Water Res. 46(10) 3167-3176.

Schets, F.M., Schijven, J.F., de Roda Husman A.M., 2011. Exposure assessment for swimmers in bathing waters and swimming pools. Water Res. 45, 2392-2400.

Schwartz, M.L., 2005. Encyclopedia of coastal science. Springer, Dordrecht, The Netherlands.

Seredyńska-Sobecka, B., Stedmon, C.A., Boe-Hansen, R., Waul, C.K., Arvin, E., 2011. Monitoring organic loading to swimming pools by fluorescence excitation-emission matrix with parallel factor analysis (PARAFAC). Water Res. 45(6), 2306-2314.

Shani, J., Kushelevsky, A.P., Harari, M., Even-Paz, Z.V.I., 1995. Sustained decrease of blood pressure in psoriatic patients during treatment at the dead sea. Pharmacol. Res. 31(6), 355359. 
Shirodkar, P.V., Mesquita, A., Pradhan, U.K., Verlekar, X.N., Babu, M.T., Vethamony, P., 2009. Factors controlling physico-chemical characteristics in the coastal waters off Mangalore-A multivariate approach. Environmental Res. 109(3), 245-257.

Smith, M., Puczko, L., 2009. Health and Wellness Tourism. Elsevier's Science \& Technology, Oxford, U.K. http://spss.en.softonic.com/ SPPS Statistics 17.0.

Tardif, R., Catto, C., Haddad, S., Simard, S., Rodriguez, M., 2016. Assessment of air and water contamination by disinfection by-products at 41 indoor swimming pools. Environmental Res. 148, 411-420.

Tian, C., Liu, R., Guo, T., Liu, H., Luo, Q., Qu, J., 2013. Chlorination and chloramination of high-bromide natural water: DBPs species transformation. Sep. Purif. Technol. 102, 86-93.

Tsuchiya, Y., Shimizu, T., Tazawa, T., Nakamura, K., Yamamoto, M., 2003a. Effects of Hot Deep Seawater Bathing on the Immune Cell Distribution in Peripheral Blood from Healthy Young Men. Environ. Health Prev. 8, 161-165.

Tsuchiya, Y., Shimizu, T., Tazawa, T., Shibuya, N., Nakamura, K., Yamamoto, M., 2003 b. Changes in plasma lactate and pyruvate concentrations after taking a bath in hot deep seawater. Tohoku J. Exp. Med., 201(4), 201-211.

Urbansky, E. T.; Freeman, D. M.; Javier Rubio, F. Ascorbic acid reduction of residual active chlorine in potable water prior to halocarboxylate determination. J. Environ. Monit. $2000,2,253-256$.

Weaver, W.A., Li, J., Wen, Y., Johnston, J., Blatchley, M.R., Blatchley III, E.R., 2009. Volatile disinfection by-product analysis from chlorinated indoor swimming pools. Water Res. 43(13), 3308-3318.

Weng, S.C., Blatchley III, E.R., 2011. Disinfection by-product dynamics in a chlorinated, indoor swimming pool under conditions of heavy use: National swimming competition. Water Res. 45(16), 5241-5248.

World Health Organization (WHO) (2006). Guidelines for safe recreational water environments. Volume 2: Swimming pools and similar environments. Geneva, retrieved from http://www.who.int/water_sanitation_health/bathing/bathing2/en/.

Xu, X., Mariano, T.M., Laskin, J.D., Weisel, C.P., 2002. Percutaneous absorption of trihalomethanes, haloacetic acids, and haloketones. Toxicol. App. Pharm. 184(1), 19-26. 